\title{
The Availability of Skills among Workers in Commercial Banks in Aqaba, Jordan: Hashemite Kingdom of Jordan: An Exploratory Study in National Banks in the City of Aqaba-Jordan
}

\author{
Dr. Burhan M Awad Al-Omari \\ College of Administrative and Finance Business Studies Department \\ E-mail: burhanalomari@yahoo.com
}

Received: February 13, 2012 Accepted: February 21, $2012 \quad$ Published: April 1, 2012

doi:10.5296/jmr.v4i2.1388 URL: http://dx.doi.org/10.5296/jmr.v4i2.1388

\begin{abstract}
The aim of this study is to identify the impact of computerized management information systems in the performance of workers in the commercial banks of Aqaba-Jordan, a questionnaire was developed and designed to achieve the objectives of this study in order to collect data, and was distributed on the sample of (92) employees from various commercial banks in Aqaba-Jordan, in a set of 8-10 questionnaires for each bank, (88) questionnaires have been restored in a percentage of $93 \%$. The questionnaire was based on closed type of questionnaires. The researcher has calculated several statistical measures, namely arithmetic average, Alpha Cronbach's coefficient, $t$ test, standard deviation, ANOVA, and Toki test. The acceptance criteria for hypotheses or question (item) were that the arithmetic mean should be greater than 3.00 and to be significant, the observed significance level of $t$ must be less than 0.05 .
\end{abstract}

Also this study aimed to investigate the perceptions of the sample about the dimensions of the information systems for job performance requirements, programming requirements, human requirements and material requirements, The followings represent the most important results of the study:

1. There is a relationship between the characteristics of the beneficiaries and their attitudes towards management information systems.

2. The level of utilization of information systems is influenced by the attitudes of the beneficiaries towards the adoption of computer in the applications of information systems and by their attitudes toward the requirements of information systems and information systems 
activities, which are attributable to demographic variables (gender, scientific qualifications, experience, and job level).

Keywords: Commercial Banks, Management, Skills, Jordan 


\section{Introduction}

The skills of workers in the banking sector are considered of the distinguishing factors of the successful business organizations in the mean time. Business organizations currently are moving towards applying total quality management which emphasized the necessity of increased attention to the skills of workers particularly self-oriented teams, and allow employees to act freely in the face of work problems and provide them with the necessary powers to enable optimal performance. Surely the creative skills will help workers to cope with those problems and difficulties they face in the work environment and qualify to do so perfectly.

This study intends to configure [the level of skills among workers in commercial banks in Aqaba, Jordan]. Moreover to identify the skills those contribute effectively to make work groups able to accomplish their tasks efficiently and effectively. Proceeding from the premise that the Organization's real strength lies not in the power of capital or in the large number of employees, but in the ability of workers through the use of creative, practical and behavioral etc. skills which help creative excellence in performance and knowledge.

Organization that seeks to reach and maintain an outpost in the area of increased competition, especially in financial and investment fields must rely on the creative skills of their employees. Because the creative skills generate new ideas for dealing with problems and difficulties and product development and participate in the formulation of ideas that help to implement them and afford the risk consequences when change in product is made and to commensurate with the needs and tastes of consumers. Skills of workers alone are not enough to make progress but it should be organized in an integrated and coherent framework so that those skills are integrated and are resembled to accomplish the work. This change requires shifting towards sustainable management in action and continuous improvement of the skills and reviewing of structures and foundations and providing adequate support, including the freedom of the workers.

\section{The Problem of the Study}

Commercial banks under the global financial crisis, urgently need to review the equipping of manpower and their training so that they can perform the competitive outstanding work not only at the national level but also the regional and international levels, as well as reconsideration of the management information systems and its material, software, human and organizational requirements to help them align with the requirements of the current time.

One of the most important measures of the sophistication of management information systems and their role in performance improvement is the availability of material, programming, human and organizational requirements.

Therefore the study problem was generated and related to the availability of these requirements in Aqaba commercial banks and their positive impact on the performance of employees. Therefore, this study would answer the following questions: 


\section{Macrothink}

Journal of Management Research

ISSN 1941-899X

2012, Vol. 4, No. 2

1. Is there a statistically significant positive impact of the available material requirements in Aqaba commercial banks on the performance of the employees in those banks?

2. Is there a statistically significant positive impact of the available software requirements in Aqaba commercial banks on the performance of the employees in those banks?

3. Is there a statistically significant positive impact of the available human requirements in Aqaba commercial banks on the performance of the employees in those banks?

4 Is there a statistically significant positive impact of the available organizational requirements in Aqaba commercial banks on the performance of the employees in those banks?

5. Are there statistically significant differences of the impact of management information systems on the performance of employees in Aqaba banks due to demographic variables personal respondents?

\section{Importance of the Study}

The importance of this study emerges from the followings:

1. Identification of what is new in the field of management information systems.

2. The importance of the population of the study represented by the banking sector and its role in economic development.

3. The identification of the impact of the management information systems on the performance of workers in Aqaba banks may help in the improvement and development of these systems particularly in the areas that may be negative.

4. The scarcity of studies that investigate the impact of management information systems on the performance of employees in the banking sector.

\section{The Objectives of the Study}

This study aims to achieve the following objectives:

1. Identify the impact of material requirements in the commercial banks of Aqaba on the performance of its employees.

2. Identify the impact of software requirements in the commercial banks of Aqaba on the performance of its employees.

3. Identify the impact of human requirements in the commercial banks of Aqaba on the performance of its employees.

4. Identify the impact of organizational requirements in the commercial banks of Aqaba on the performance of its employees.

\section{Hypotheses of the Study}

This study tests the following hypotheses: 
1. There is no statistically significant positive impact of the available material requirements in Aqaba commercial banks on the performance of its employees.

2. There is no statistically significant positive impact of the available software requirements in Aqaba commercial banks on the performance of its employees.

3. There is no statistically significant positive impact of the available human requirements in Aqaba commercial banks on the performance of its employees.

4. There is no statistically significant positive impact of the available organizational requirements in Aqaba commercial banks on the performance of its employees.

5. There are no statistically significant differences of the impact of management information systems on the performance of employees in Aqaba banks due to demographic variables personal respondents.

\section{The methodology of the Study}

The study adopted the analytical and descriptive approach, collecting primary data from the population of the study using a questionnaire and statistically analyzed it to reach the results.

\section{The Population and the Sample of the Study}

The commercial banks operating in Aqaba represent the population of the study. 12 banks were chosen randomly as the sample of the study.

\section{The Instrument of the Study}

A questionnaire was used to collect the primary data required by the process of measuring the reality represented by the availability of the requirements of management information systems in the banks of Aqaba and its impact on the performance of the employees. Ninety five items of the questionnaire were distributed to the various banks in a set of (8-10) questionnaires for each bank, and 88 questionnaires have been restored in a percentage of $93 \%$. The questionnaire was based on the closed type, where the available answers are (strongly agree, agree, neutral, disagree, and strongly disagree). And the previous answers have been given the following weights $(5,4,3,2,1)$ respectively.

\section{The Statistical Methods Used in Hypotheses Testing}

The researcher has calculated several statistical measures, namely arithmetic average, Alpha Cronbach's coefficient, t test, standard deviation, ANOVA, and Toki test. The acceptance criteria for hypotheses or question (item) were that the arithmetic mean should be greater than 3.00 and to be significant, the observed significance level of t must be less than 0.05 .

\section{Previous Studies}

Saudi study, 2006, This study showed the impact of computerized management information systems in the performance of employees, using a sample of (369) staff member of the study population. It was concluded from this study that the respondents' perceptions toward the requirements of the operation of the information systems has a high degree. And respondents' 
perceptions towards job performance were moderate. There is an impact of the main requirements to manage the operation of the computerized information system (material, human, organizational and software) functionality. The study showed that there are statistically significant differences between respondents' perceptions of the requirements of operation of information systems attributed to demographic variables (gender, qualifications, experience, and job title). It was also shown that there are statistically significant differences between respondents' perceptions of job performance, due to demographic variables (gender, qualifications, experience, job title).

Study Tarawneh and Al-Salihi, 2005, The study examined the creative skills of the staff of the commercial banks in Irbid. The study recommended the need to develop creative skills scale in the administrative and the technical areas with identifying the skills required in both technical and administrative areas. And the need of diagnosing of humanitarian and leadership skills, with emphasizing on creative skills in business organizations. Identifying creative skills for managers in solving problems and achieving results in the area of specialization of knowledge since the work of the director includes these three areas.

Study of Haddad, 2000, This study aimed to identify the reality of teamwork in Jordanian organizations indicating that the teamwork forms a common strategy between many entries and management techniques such as quality management and organization development, and that teamwork embodies the skills and knowledge of modern management. The study recommended the need to create the right atmosphere in business organizations, including the creation of comprehending institutional systems and investment of the available opportunities and start the progressive implementation, and the need for comparative studies and activate the necessary academic role in the practice of teams, and knowledge of its constraints.

Study of Poister, 1999, The aim of this study was to determine the extent of the interference of the performance measurement in local administrations and the sample included senior management staff; the study found that there is a focus on improving the quality of the service, feedback from customers in the public sector, and one of the most important elements of performance appraisal used by the management: improving the quality of decisions, improving the quality of service, reducing costs, responsibility of managers, improving the motivation of the personnel, increasing the focus of the employees on the Organization's objectives.

Through the review of previous studies it was found that there are differences between them and the current study since this study is applied in the field of the questionnaire whereas the previous studies were applied in other fields, moreover this study has linked computerized management information systems with the performance of employees which had been directly done by the various studies except only one study.

Study of Ismail, 1999, The study aimed to determine the characteristics of beneficiaries (individual, functional, professional), as well as to identify the nature of the need of information of the beneficiaries to identify the nature of the link and the impact between the characteristics of beneficiaries and their attitude towards information systems, where a sample of 112 decision makers from the population was taken, the main findings of the study is that there is a relationship between the characteristics of the beneficiaries and their 
attitudes towards management information systems. The level of utilization of information systems is influenced by the attitudes of the beneficiaries towards the adoption of computer in the information systems applications and by their attitudes toward the requirements for information systems and activities of the system.

Study Al-A'ouar, 1999, The aim of this study is to examine the reality of computer use and to identify the use computers in the control, the supervision, the operational stability, the satisfaction and the functionality. It was found that computer use has led to improve the functionality, the creativity and initiative of the employees and to improve the employees' satisfaction.

Study of Naseer, 1998, This study aimed to identify the opinions of managers about the availability features of teamwork in governmental agencies for the northern governorates in Jordan. The study found that teamwork attributes (such as participation, facilitation, openness, cooperation, sensitivity, flexibility, commitment, and risk tolerance) moderately available to managers. The study emphasizes the need to focus on training to develop teamwork attributes to reach the highest level. The study recommended the need for attention in the selection of team members to meet the expertise and skills necessary to accomplish the task.

Study of Cabelman, 1996, This study pointed to some of the psychosocial consequences of the training of the end user of the information system in the early stages of the implementation.

The study was concerned of applying the theory of behavioral trends on the success of information system, the theoretical side included differentiation between user trends towards system development process and their attitudes towards information system after the development process. The study concluded that user involvement in training not directly contribute to success of the information systems but contributes to the estimation of user mode and his needs, in order to understand the success of information system within the individual user level, the psychological dimensions of the user should be taken into consideration, and that requires knowledge of the impact of training on user satisfaction as well as their attitude towards system information. The study showed that the training received by the user to use the system information to serve as a delegation to the user to participate in the development of information systems, therefore the training becomes an indirect stimulus to the user to accept the system and this affects the satisfaction of the beneficiary of the information system.

Study of Wilson, 1996, The aim of this study was to identify the satisfaction of the decision makers from the used information system; this study also examined the impact of demographic variables (age, sex, level of education) on the decision-making process.

The study found that decision-makers have some concerns of using computers; it found that employees need incentives to accept the system, and suggested to encourage the employees to express their needs of information so as to get rid of the anxiety of computer use.

Study of Al-Shannaq, 1994, The study included a sample "53" out of "103" companies listed on Amman financial market, and aimed to detect the availability of management information systems in the Jordanian public shareholding companies, and the degree of benefit as well as the degree of impact on organizational performance of these companies. The study found that 
"53.24" percent of companies have a special section or department of information management, and there was no significant effect of the existence of the section or department on institutional performance. The concern about information systems is very little in the majority of the companies. There is no impact of hardware and software on the institutional performance. And there is no positive impact of management information system on institutional performance.

\section{Instrument Stability}

The stability of the instrument has been tested by testing Alpha Cronbach's coefficient, given in table (1) shows the following:

1. Alpha value for paragraphs of material supplies dimension 0.79

2. The alpha value of dimension supplies code 0.83

3. The alpha value of human necessities dimension 0.71

4-alpha value of organizational supplies dimension 0.84

5. Alpha value for all paragraphs 0.91

All these values are higher than 0.60 , which means that there is stability in the study tool.

Table 1. Alpha Cronbach's coefficient test results of the study axes:

\begin{tabular}{|l|l|}
\hline Dimension & Alpha Value \\
\hline Material requirements & 0.79 \\
\hline Program requirements & 0.83 \\
\hline Human requirements & 0.71 \\
\hline Organizational requirements & 0.84 \\
\hline Sum & 0.91 \\
\hline
\end{tabular}

\section{Description of the Personal and Demographic Factors of the Respondents}

Table (2) presents a description of the personal factors to the individuals of the sample working in the banks that comes as follows:

Specialty: $30.68 \%$ of the sample have a major in finance, $22.73 \%$ have a major in management information systems, $20.45 \%$ has a major in accounting, $17.05 \%$ have a major in business administration, $3.41 \%$ have a major in economics, and $5.68 \%$ have major in other specialties.

Scientific degree: as it is shown from the sample, $50 \%$ of it were of the bachelor holder, $42.05 \%$ of it were of diploma holders, $5.68 \%$ of it were of master holder and $2.27 \%$ were of the general certificate holders. 


\section{Macrothink}

Journal of Management Research

ISSN 1941-899X

2012, Vol. 4, No. 2

Experience: it was shown from the sample that $40.91 \%$ of it have $6-10$ years of experience, $36.36 \%$ have $1-5$ years of experience, $12.50 \%$ have $11-15$ years of experience, and $10.23 \%$ their experience exceed 15 years.

Job level: as shown in the table there are approximately $4.32 \%$ who just employees, whereas 30.68 are department heads, $20.45 \%$ are deputy directors, and $4.55 \%$ are managers

Table 2. Frequencies and percentages of the personal variables of the respondents:

\begin{tabular}{|c|c|c|c|}
\hline Factor & & Frequency & Percentage \\
\hline \multirow[t]{6}{*}{ Specialty } & Business Administration & 15 & 17.05 \\
\hline & Finance & 27 & 30.68 \\
\hline & Accounting & 18 & 20.45 \\
\hline & MIS & 20 & 22.73 \\
\hline & Economics & 3 & 3.41 \\
\hline & Others & 5 & 5.68 \\
\hline \multirow[t]{4}{*}{ Scientific Degree } & General Secondary Certificate & 2 & 2.27 \\
\hline & Diploma & 37 & 42.05 \\
\hline & Bachelor & 44 & 50.00 \\
\hline & Master & 5 & 5.68 \\
\hline \multirow[t]{4}{*}{ Experience } & $1-5$ & 32 & 36.36 \\
\hline & $6-10$ & 36 & 40.91 \\
\hline & $11-15$ & 11 & 12.50 \\
\hline & More than 15 years & 9 & 10.23 \\
\hline \multirow[t]{4}{*}{ Job Level } & Manager & 4 & 4.55 \\
\hline & Deputy Director & 18 & 20.45 \\
\hline & Section Head & 27 & 30.68 \\
\hline & Employee & 39 & 44.32 \\
\hline
\end{tabular}

\section{Hypotheses Testing and Results Analysis}

\subsection{First Hypothesis}

There is no statistically significant positive impact of the available material requirements in Aqaba commercial banks on the performance of its employees.

It has been shown from table (3) that: 
1-All the items were statistically significant as they have arithmetic averages greater than 3.00 and the observed significance level less than 0.005 which means that these things were available in the banks except items 3 and 5 .

Item 1, which measures the extent of the availability of suitable computer devices to complete the required work, comes in the first rank with an arithmetic average of 4.17 , next comes item 7 , item 2 , then item 4 consequently. But item 6 , which measures the extent of the availability of the distinguish of the available information network by sufficient communication speed to achieve the required work, comes in the last position among the statistically accepted items with an arithmetic average of 3.23

2-Item 3, which measures the extent of the availability of data entry tools suitable with the needs of the work in the banks, has an arithmetic average of 2.52 which is less than 3.00 which indicates that it is not statistically significant.

3-Item 5, which measures the extent of the convenience of the available information network with the needs of the work in the banks, has an arithmetic average of 2.43 which is less than 3.00 which indicates that it is not statistically significant.

In order to test the first hypothesis, it was found that the arithmetic average of the items all together equals 3.45 with a significance level of 0.00 , so we reject the first hypothesis, that is, there is statistically significant positive impact of the available material requirements in Aqaba commercial banks on the performance of its employees.

Table 3. Arithmetic average, standard deviation, $t$-value and the observed significance level for the material requirements:

\begin{tabular}{|c|c|c|c|c|c|}
\hline $\begin{array}{l}\text { Item } \\
\text { No. }\end{array}$ & Item & $\begin{array}{l}\text { Arithmetic } \\
\text { average }\end{array}$ & S.D & $\mathrm{t}$ & $\alpha$ \\
\hline 1 & $\begin{array}{l}\text { The suitable computer devices to perform the } \\
\text { required work are available }\end{array}$ & 4.17 & 0.55 & 19.92 & 0.00 \\
\hline 2 & $\begin{array}{l}\text { The system provide sufficient areas for the } \\
\text { storage process }\end{array}$ & 3.91 & 0.47 & 18.12 & 0.00 \\
\hline 3 & $\begin{array}{l}\text { The entry tools which are suitable with the need } \\
\text { of the wok in the banks are available }\end{array}$ & 2.52 & 0.98 & -4.56 & 0.00 \\
\hline 4 & $\begin{array}{l}\text { The output devices are suitable with the needs } \\
\text { of the work in the banks }\end{array}$ & 3.83 & 0.51 & 15.32 & 0.00 \\
\hline 5 & $\begin{array}{l}\text { The available information network is } \\
\text { convenient with the needs of the work in the } \\
\text { banks }\end{array}$ & 2.43 & 0.94 & -5.64 & 0.00 \\
\hline 6 & $\begin{array}{l}\text { The available information network is } \\
\text { characterized by the sufficient speed to achieve } \\
\text { the required work }\end{array}$ & 3.23 & 0.66 & 3.25 & 0.00 \\
\hline 7 & $\begin{array}{l}\text { There are modern communication techniques } \\
\text { that are highly efficient }\end{array}$ & 4.07 & 0.40 & 25.35 & 0.00 \\
\hline & Total & 3.45 & 0.29 & 14.67 & 0.00 \\
\hline
\end{tabular}




\subsection{Second Hypothesis}

There is no statistically significant positive impact of the available software requirements in Aqaba commercial banks on the performance of its employees.

It has been shown from table (4) that:

1. All the items were statistically significant as they have arithmetic averages greater than 3.00 and the observed significance level less than 0.005 which means that these things were available in the banks except items 9,11 and 12.

Item 13, which measures the extent of the availability of all the required instructions to operate the software in the work performance, comes in the first rank with an arithmetic average of 4.07, next comes item 16, item 17, item 8 then item 10 consequently. But item 15, which measures the extent of the to which the software provide information precisely to achieve the required work, comes in the last position among the statistically accepted items with an arithmetic average of 3.39

2. Item 9, which measures the extent that the software is updated to be convenient with the need of the banks work has an arithmetic average of 2.81 which is less than 3.00 which indicates that it is not statistically significant.

3. Item 11, which measures the extent of the coverage of the used software to all activities performed by the banks, has an arithmetic average of 2.88 which is less than 3.00 which indicates that it is not statistically significant.

4. Item 12, which measures the extent to which software are characterized by flexibility and simplicity, has an arithmetic average of 3.07 which is greater than 3.00 but the significance level is greater than 0.05 which indicates that it is not statistically significant.

5. According to the second hypothesis, it was found that the arithmetic average of the items all together equals 3.55 with a significance level of 0.00 , so we reject the second hypothesis, that is, there is a statistically significant positive impact of the available software requirements in Aqaba commercial banks on the performance of its employees. 
Table 4. Arithmetic average, standard deviation, $t$-value and the observed significance level for the software requirements

\begin{tabular}{|c|c|c|c|c|c|}
\hline $\begin{array}{l}\text { Item } \\
\text { No. }\end{array}$ & Item & $\begin{array}{l}\text { Arithmetic } \\
\text { average }\end{array}$ & S.D & $\mathrm{t}$ & $\alpha$ \\
\hline 8 & $\begin{array}{l}\text { The used software is convenient with the } \\
\text { requirements of banks work }\end{array}$ & 3.72 & 0.64 & 10.46 & 0.00 \\
\hline 9 & $\begin{array}{l}\text { Software is updated conveniently with need of } \\
\text { banks work }\end{array}$ & 2.81 & 1.35 & $1.35-$ & 0.18 \\
\hline 10 & $\begin{array}{l}\text { The used software is compatible with the } \\
\text { devices used in the work }\end{array}$ & 3.68 & 0.67 & 9.54 & 0.00 \\
\hline 11 & $\begin{array}{l}\text { The used software covers all the activities } \\
\text { performed by the bank }\end{array}$ & 3.07 & 1.36 & 0.47 & 0.64 \\
\hline 12 & $\begin{array}{l}\text { The used software is characterized by } \\
\text { flexibility and simplicity }\end{array}$ & 2.88 & 0.92 & $1.28-$ & 0.21 \\
\hline 13 & $\begin{array}{l}\text { All the needed instruction for operating } \\
\text { software in work performance is available }\end{array}$ & 4.07 & 0.33 & 30.18 & 0.00 \\
\hline 14 & $\begin{array}{l}\text { Software provide information with the suitable } \\
\text { quality required to achieve the required work }\end{array}$ & 4.05 & 0.40 & 24.61 & 0.00 \\
\hline 15 & $\begin{array}{l}\text { Software provides information with the } \\
\text { required precision for performing the required } \\
\text { work }\end{array}$ & 3.39 & 0.58 & 6.29 & 0.00 \\
\hline 16 & $\begin{array}{l}\text { Software provide the suitable security systems } \\
\text { of the information }\end{array}$ & 4.05 & 0.34 & 29.19 & 0.00 \\
\hline 17 & $\begin{array}{l}\text { The used Software help in restoring } \\
\text { information rapidly }\end{array}$ & 3.77 & 0.60 & 12.06 & 0.00 \\
\hline & Total & 3.55 & 0.36 & 14.38 & 0.00 \\
\hline
\end{tabular}

\subsection{Third Hypothesis}

There is no statistically significant positive impact of the available human requirements in Aqaba commercial banks on the performance of its employees.

It has been shown from table (5) that:

1. All the items were statistically significant as they have arithmetic averages greater than 3.00 and the observed significance level less than 0.005 which means that these things were available in the banks except item 20. Item 18, which measures the distinguish of the workers in the relevant section with the adequate skills, comes in the first rank with an arithmetic average of 4.01, next comes item 24, item 19, item 22 then item 21 consequently. But item 23, which measures how much help the training courses offered by banks in management information systems increases the effectiveness of the performance of employees, comes in the last position among the statistically accepted items with an arithmetic average of 3.25 
2. Item 20, which measures how quickly respond to the inquiries of the technical section specialized in information system, has an arithmetic average of 2.52 which is less than 3.00 which indicates that it is not statistically significant.

3. According to the third hypothesis, it was found that the arithmetic average of the items all together equals 3.56 with a significance level of 0.00 , so we reject the third hypothesis, that is, there is a statistically significant positive impact of the available human requirements in Aqaba commercial banks on the performance of its employees.

Table 5. Arithmetic average, standard deviation, $t$-value and the observed significance level for the human requirements:

\begin{tabular}{|c|c|c|c|c|c|}
\hline $\begin{array}{l}\text { Item } \\
\text { No. }\end{array}$ & Item & $\begin{array}{l}\text { Arithmetic } \\
\text { average }\end{array}$ & S.D & $\mathrm{t}$ & $\alpha$ \\
\hline 18 & $\begin{array}{l}\text { The workers in the section specialized in } \\
\text { information system are characterized by } \\
\text { adequate skills }\end{array}$ & 4.01 & 0.42 & 22.86 & 0.00 \\
\hline 19 & $\begin{array}{l}\text { the technical section specialized in information } \\
\text { system treat the problems facing the users of } \\
\text { the network efficiently }\end{array}$ & 3.97 & 0.44 & 20.56 & 0.00 \\
\hline 20 & $\begin{array}{l}\text { The technical section quickly respond to the } \\
\text { inquiries }\end{array}$ & 2.52 & 1.13 & -3.95 & 0.00 \\
\hline 21 & $\begin{array}{l}\text { The section responsible for information system } \\
\text { is directly contacted }\end{array}$ & 3.47 & 0.66 & 6.62 & 0.00 \\
\hline 22 & $\begin{array}{l}\text { The training courses in MIS achieve the } \\
\text { requirements and the needs of the workers }\end{array}$ & 3.76 & 0.64 & 11.11 & 0.00 \\
\hline 23 & $\begin{array}{l}\text { The training courses in MIS provided by the } \\
\text { bank help in increasing the effectiveness of the } \\
\text { performance of the worker }\end{array}$ & 3.25 & 0.59 & 3.96 & 0.00 \\
\hline 24 & $\begin{array}{l}\text { The suitable training courses in MIS held } \\
\text { according to the needs of the workers }\end{array}$ & 3.98 & 0.48 & 19.14 & 0.00 \\
\hline & Total & 3.56 & 0.48 & 12.62 & 0.00 \\
\hline
\end{tabular}

\subsection{Fourth Hypothesis}

There is no statistically significant positive impact of the available organizational requirements in Aqaba commercial banks on the performance of its employees.

It has been shown from table (6) that:

1. All the items were statistically significant as they have arithmetic averages greater than 3.00 and the observed significance level less than 0.005 which means that these things were available in the banks except item 28. Item 25, which measures The extent to which the senior management to provide the necessary financial support for the use of information system, comes in the first rank with an arithmetic average of 4.26, next comes item 26, item 32, item 29, item 30 then item 27 consequently. But item 31, which measures how much the senior management makes the needed requirements for improving the usage of management 
information systems available, comes in the last position among the statistically accepted items with an arithmetic average of 3.42

2. Item 28 , which measures the extent to which any organizational level obtains information that obtained by another organizational level within the same section, has an arithmetic average of 2.05 which is less than 3.00 which indicates that it is not statistically significant.

3. According to the fourth hypothesis, it was found that the arithmetic average of the items all together equals 3.60 with a significance level of 0.00 , so we reject the fourth hypothesis, that is, there is a statistically significant positive impact of the available organizational requirements in Aqaba commercial banks on the performance of its employees.

Table 5. Arithmetic average, standard deviation, t-value and the observed significance level for the organizational requirements:

\begin{tabular}{|c|c|c|c|c|c|}
\hline $\begin{array}{l}\text { Item } \\
\text { No. }\end{array}$ & Item & $\begin{array}{l}\text { Arithmetic } \\
\text { average }\end{array}$ & S.D & $\mathrm{t}$ & $\alpha$ \\
\hline 25 & $\begin{array}{l}\text { The senior management provides the required } \\
\text { financial support to use the information system }\end{array}$ & 4.26 & 0.70 & 16.83 & 0.00 \\
\hline 26 & $\begin{array}{l}\text { The senior management cares about the } \\
\text { opinions and the recommendations of the } \\
\text { workers on the information system }\end{array}$ & 4.14 & 0.78 & 13.74 & 0.00 \\
\hline 27 & $\begin{array}{l}\text { It is easy to get the information that is available } \\
\text { for the senior management }\end{array}$ & 3.50 & 1.52 & 3.08 & 0.00 \\
\hline 28 & $\begin{array}{l}\text { each organizational level could obtain } \\
\text { information that is available for any other level } \\
\text { within the same section }\end{array}$ & 2.05 & 1.02 & -8.81 & 0.00 \\
\hline 29 & $\begin{array}{l}\text { Senior Management monitors the workflow } \\
\text { that is based on the use of management } \\
\text { information systems }\end{array}$ & 3.75 & 0.68 & 10.31 & 0.00 \\
\hline 30 & $\begin{array}{l}\text { The available information is compatible with } \\
\text { the needs of the work needed to achieved }\end{array}$ & 3.69 & 1.40 & 4.64 & 0.00 \\
\hline 31 & $\begin{array}{l}\text { The senior management provides the needed } \\
\text { requirements to improve the usage of the } \\
\text { management information system }\end{array}$ & 3.42 & 1.61 & 2.45 & 0.02 \\
\hline 32 & $\begin{array}{l}\text { The senior management is concerned about } \\
\text { developing the used information system }\end{array}$ & 4.01 & 0.67 & 14.17 & 0.00 \\
\hline & Total & 3.60 & 0.41 & 13.91 & 0.00 \\
\hline
\end{tabular}

\subsection{Fifth Hypothesis}

There are no statistically significant differences of the impact of management information systems on the performance of employees in Aqaba banks due to demographic variables personal respondents.

It has been sown from table (7) that: 
First: specialty

All the observed significance levels of all the dimensions is greater than 0.05 , so there is no difference that are statistically significant to the impact of the management information systems on the performance of the workers attributed to the specialty of the respondents variable.

\section{Second: scientific degree}

All the observed significance levels of all the dimensions is greater than 0.05 , so there is no difference that are statistically significant to the impact of the management information systems on the performance of the workers attributed to the scientific degree variable.

\section{Third: experience}

All the observed significance levels of all the dimensions is greater than 0.05 , so there is no difference that are statistically significant to the impact of the management information systems on the performance of the workers attributed to experience variable.

Fourth: job level

All the dimensions have observed significance levels greater than 0.05 , accept the dimension of material requirements, which means that there are no differences that is statistically significant in the impact of management information system on the performance of the workers related to software, human, and organizational requirements attributed to job level variable.

The observed significance level of the material requirements was 0.01 which means that there are differences attributed to job level variable. In order to verify the source of these differences, Toki test was performed as sown in table (7), which indicates that as the job level increased the feeling for material requirements increased. But the statistical differences equal 4 differences, the first and the second between the managers from one side and department heads and employees for the advantage of the first, the third and the fourth between the employees from one side and deputy directors and department heads for the advantage of the last to parts.

Table 7. Observed significance levels of the ANOVA test

\begin{tabular}{|l|r|r|r|r|}
\hline Dimension & \multicolumn{1}{|l|}{ Specialty } & \multicolumn{1}{|l|}{ Scientific degree } & Experience & Job level \\
\hline Material requirements & 0.28 & 0.54 & 0.39 & 0.01 \\
\hline Software requirements & 0.71 & 0.72 & 0.12 & 0.14 \\
\hline Human requirements & 0.18 & 0.23 & 0.08 & 0.10 \\
\hline Organizational requirements & 0.44 & 0.62 & 0.50 & 0.07 \\
\hline
\end{tabular}


Table 8 . the results of Toki test

\begin{tabular}{|l|l|l|l|l|}
\hline & Manager & Deputy director & Department head & Employee \\
\hline Manager & ------ & & & \\
\hline Deputy director & 0.45 & ------ & & \\
\hline Department head & $0.92^{*}$ & 0.47 & ------ & \\
\hline Employee & $1.54^{*}$ & $1.09 *$ & $0.62^{*}$ & ------ \\
\hline
\end{tabular}

\section{Results}

The study concluded the followings:

There is a positive statistically significant impact of the available material requirements in Aqaba commercial banks on the performance of the workers in these banks. As the computer devices which are convenient to perform the required work are available, also the output devices suitable with the needs of the work are available. The system provides sufficient storage areas. The available communication techniques are modern and of high efficiency. But the entry devices are not suitable with the needs of the work also the available information network is suitable with the needs of the works in the banks.

There is a positive statistically significant impact of the available software requirements in Aqaba commercial banks on the performance of the workers in these banks. As all the required instructions to operate software are available for performing the work. The softwares provide the information with the required quality and the required accuracy to perform the work, and provide the security systems suitable with the information. These softwares help in restoring information quickly and meet with the requirements of the work and with the devices used. But the softwares have not been updated to suit with the requirements of the work. These softwares do cover all activities performed by the banks and is not characterized by simplicity and flexibility.

There is a positive statistically significant impact of the available human requirements in Aqaba commercial banks on the performance of the workers in these banks. As the workers in the section specialized in information system are characterized by adequate skills, and the technical section specialized in information system treat the problems facing the users of the network efficiently, also the section responsible for information system is directly contacted, in addition the training courses in MIS achieve the requirements and the needs of the workers and The training courses in MIS provided by the bank help in increasing the effectiveness of the performance of the worker plus that The suitable training courses in MIS held according to the needs of the workers. But the technical section did not quickly respond to the inquiries.

There is a positive statistically significant impact of the available human requirements in Aqaba commercial banks on the performance of the workers in these banks. As The senior management provides the required financial support to use the information system also the senior management cares about the opinions and the recommendations of the workers on the information system, plus it is easy to get the information that is available for the senior management, moreover senior Management monitors the workflow that is based on the use of management information systems in addition that the available information is compatible with 
the needs of the work needed to achieved and the senior management provides the needed requirements to improve the usage of the management information system, also the senior management is concerned about developing the used information system. But each organizational level could not obtain information that is available for any other level within the same section

There are no statistically significant differences in the impact of management information systems on the performance of employees due to personal variables of the respondents in Aqaba banks. With the exception of job level with regard to material requirements as it was shown that there is a positive relationship between job level and the impact of material requirements on the performance of employees.

\section{Recommendations}

The study recommends the followings:

1. Banks of Aqaba should work on the development and continuously improvement of the various requirements of management information systems because of the positive impact on the performance of employees.

2. Provision of data entry tools that commensurate with the needs of the work. Also provision of information network that is convenient to the needs of the work in Aqaba banks.

3. The need for banks of Aqaba to develop technical section specialized in information system in Aqaba banks for fast responding to queries.

4. Update software to commensurate with the need of work in banks of Aqaba, and to cover all activities undertaken by these banks, also increase the flexibility and ease of use of the software used.

5. The study recommends Aqaba banks enable organizational levels to access to information obtained by any another level within the same section.

6. Aqaba banks should study the causes of the differences felt by functional levels related to material requirements, and should try to correct the situation if needed.

\section{References}

Burhan, Mohamed Nur. (1994). management of Government information systems elements of strategies and policies, (translator), the report issued by the Department of technical cooperation for development, the United Nations, the Arab Administrative Development Organization, Oman.

Haider, h.e. Fahmi. (2002). Portal information systems to achieve competitive advantage, University House, Alexandria.

Al-Abed, Jalal Ibrahim, Manal Mohammed, \& Kurdish. (2000). Introduction to management information systems: theoretical tools applications, printing house, Alexandria University. 


\section{Macrothink}

Journal of Management Research

ISSN 1941-899X 2012, Vol. 4, No. 2

Haddad, Fareed Jamil, (2000). The reality of business organizations in action teams, a field study from the perspective of functional managers. MPhil, Yarmouk University, Irbid-Jordan.

Hassan Mohammed Abdel Ghani. (1994). Teamwork skills, performance development skill set, Cairo: Dar es Salaam books.

Hassan Mohammed Abdel Ghani. (1995). team-building skills, Cairo: Dar es Salaam books.

Harem, Hussein. (2003). Managing organizations: a quantitative perspective, Oman: Dar library al-Hamed.

Khelgeh, Hani, \& Reem sartawi.(1998). Leadership in crisis, Illinois: house of ideas international.

Nasser Mohammed, Ahmed. (1995). Human behavior and organizational comparative holistic perspective: Institute of public administration in Riyadh.

Alamyan, Mahmud Salman. (2002). Organizational behavior in business organizations, I 1, Amman: Wael publishing.

Allozi, Musa. (2002). Regulations and operating procedures, 1st edition, Amman: Wael,

Kayed, Zuhair. (1991). group dynamics. Journal of management and development, vol. 14 No. 2, p. 36.

Nasir, Naim mind. (1998). team-building: a field study of the views of managers about the availability features of teamwork in governmental agencies in the provinces of the North, public administration, folder 38, number 2, August.

Buch, J., Thomas. (1995). The Rocky Road To Team Management. Training \& Development, April.

Cook, Curtis w., \& Huseker, Plip. (2000). Management \& Organizational Pehavior, 3rd Edition, McGraw- Hill companies, Inc.

Cox, Danny, \& Hoover, John. (1998). Leadership When The Heat's on, NY: MeGraw Hill companies, Inc. 